\title{
ATTERBERG LIMIT OF KAOLINITE-LIME
}

\author{
Mahdi Keramatikerman \\ Engineer, Arup Australia, 61-73 Sturt Street, \\ Suncorp Tower, Townsville QLD 4810, Australia \\ Amin Chegenizadeh \\ Senior Lecturer, Department of Civil Engineering, \\ Hamid Nikraz \\ Professor, Department of Civil Engineering,
}

Curtin University of Technology, Kent Street, Bentley, Perth, Western Australia 6102, Australia

Curtin University of Technology, Kent Street, Bentley, Perth, Western Australia 6102, Australia

\begin{abstract}
One of the key parameters of geotechnical investigation is to Atterberg limit. With current approach in employment of stabilisation technique, there is a vital need to investigate the effect of stabilizers into Atterberg limit of mixture. This study focuses on lime effect on kaolinite liquid limit, plastic limit and plasticity index.
\end{abstract}

\section{Keywords - Atterberg, Kaolinite, Lime}

\section{INTRODUCTION}

Atterberg limit is a basic characteristic of the soil. Every soil investigation reports include Atterberg limit values [1-12]. This include liquid limit (LL) and plastic limit (PL) [13-21]. This shows workability of the soil. Lime is a cementitious material with various applications in different ground improvement sector [22-31]. For instance, lime is widely used in transport, rail and highway ground improvements [31-39]. Also, kaolinite clay is a type of soil that is abundant in the environment [40-46]. This study aims to investigate effect lime on Atterberg limit characteristics of the kaolinite clay.

\section{MATERIALS}

The material was selected with respect to their availabilities and benefit to community. They can be referred as:

\section{a) Kaolinite:}

Kaolinite was selected and sourced from a Perth's supplier. The $\mathrm{pH}$ of kaolinite was alkaline.

\section{b) Lime} $80 \%$.

The highlighted ingredients were Cao which was roughly

\section{COMPACTION TESTING}

Table 1 shows the compaction characteristics of the mixes.
Table 1 Compaction characteristics of mixes

\begin{tabular}{|l|l|l|l|}
\hline Sample Id & Lime & OMC \% & MDD \\
\hline K-L5 & 5 & 25 & 1.23 \\
\hline K-L10 & 10 & 29 & 1.18 \\
\hline K-L15 & 15 & 34 & 1.15 \\
\hline
\end{tabular}

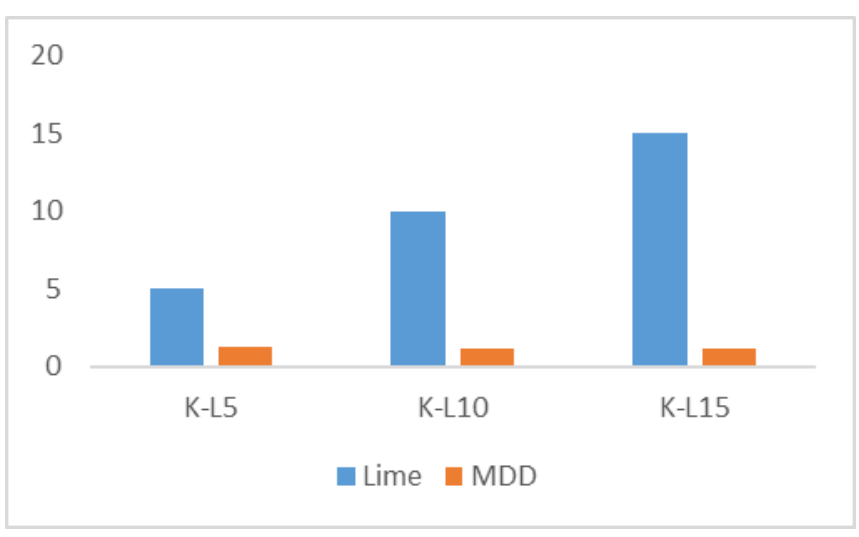

Fig. 1. Maximum dry density (MDD) of mixtures

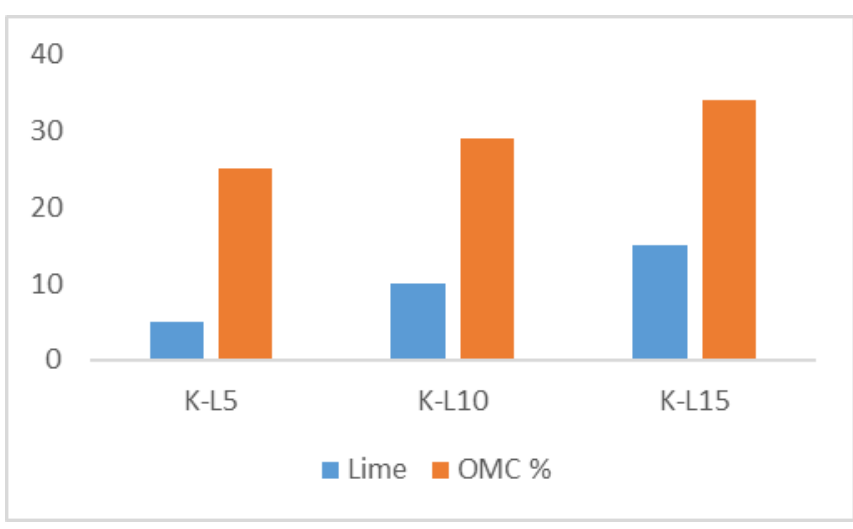

Fig. 2. Optimum moisture content (OMC) of mixtures 


\section{International Journal of Engineering Applied Sciences and Technology, 2020 \\ Vol. 4, Issue 11, ISSN No. 2455-2143, Pages 255-258 \\ Published Online March 2020 in IJEAST (http://www.ijeast.com)}

\section{ATTERBERG LIMIT}

The atterbeg limit tests were conducted for mixtures to get the values of LL,PL and PI. The following fiures repersent the changes in the baove indices with respect to changes in lime percentage.

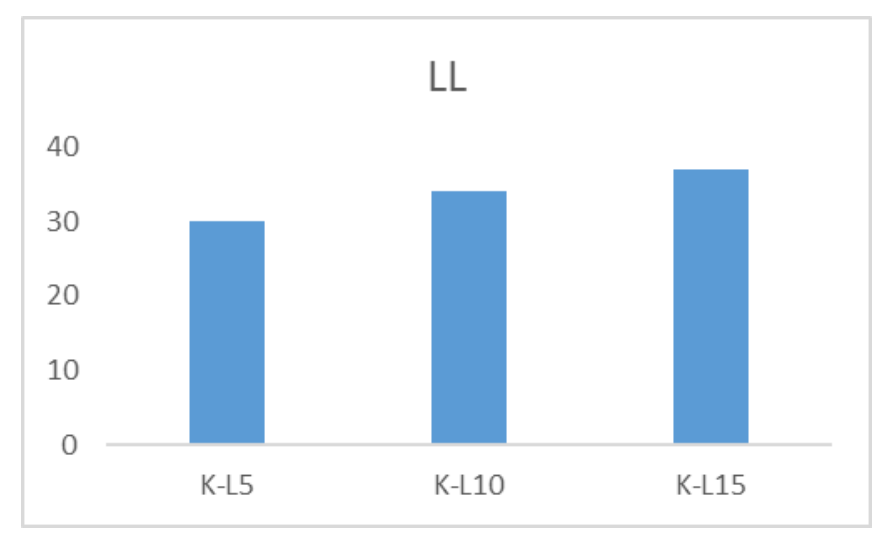

Fig. 3. Liquid limit (LL) of mixtures

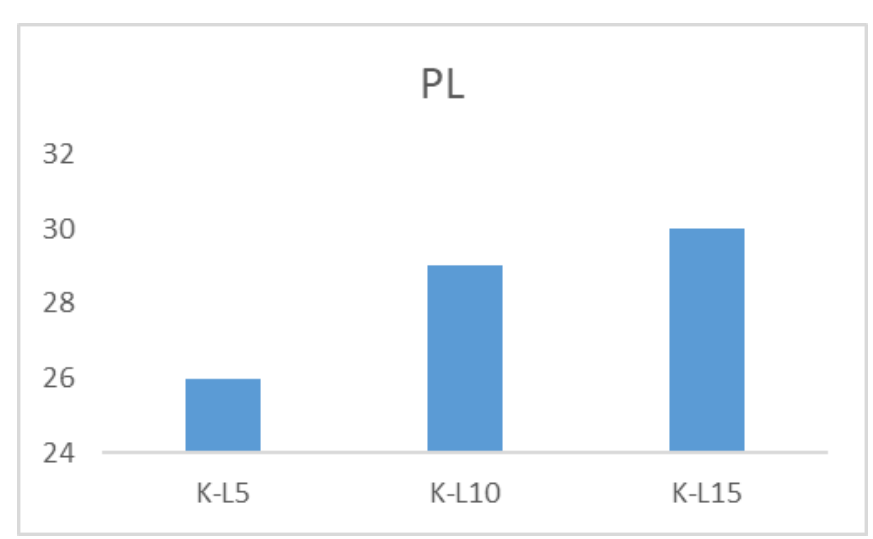

Fig. 4. Plastic limit (PL) of mixtures

\section{CONCLUSION}

A series of atterberg limit test was conducted the results showed with increasing in lime dosage LL, PL and PI increased at the same time OMC increased and MDD decreased as results of compaction tests.

\section{REFERENCES}

[1] Odell RT, Thornburn TH, McKenzie LJ. Relationships of Atterberg limits to some other properties of Illinois soils. Soil Science Society of America Journal. 1960 Jul;24(4):297-300.

[2] Chegenizadeh, A., Keramatikerman, M., \& Nikraz, H. (2017). A Study on Numerical Modelling of Rigid Pavement: Temperature and Thickness
Effect. International Journal of Civil and Environmental Engineering, 10(2), 265-269.

[3] Bouazza A, Jefferis S, Vangpaisal T. Investigation of the effects and degree of calcium exchange on the Atterberg limits and swelling of geosynthetic clay liners when subjected to wet-dry cycles. Geotextiles and Geomembranes. 2007 Jun 1;25(3):170-85.

[4] Al-Rkaby AHJ, Chegenizadeh A, Nikraz H. (2016). Directional-dependence in the mechanical characteristics of sand: A Review International Journal of Geotechnical Engineering 10 (5), 499-509

[5] Rogers CD, GLENDINNING, Roff TE. Lime modification of clay soils for construction expediency. Proceedings of the Institution of Civil EngineersGeotechnical Engineering. 1997 Oct;125(4):242-9.

[6] Keramatikerman M, Chegenizadeh A, Terzaghi S. (2019) Review on Effect of Sugarcane Bagasse Ash as an Additive in Construction Industry. 2019. EJGE. Vol.24 Bun. 02.

[7] Keramatikerman, M., Chegenizadeh, A., \& Nikraz, H. (2018). Effect of Flyash on Post-Cyclic Behavior of Sand. Journal of Earthquake Engineering, 1-13.

[8] Chew SH, Kamruzzaman AH, Lee FH. Physicochemical and engineering behavior of cement treated clays. Journal of geotechnical and geoenvironmental engineering. $2004 \mathrm{Jul} ; 130(7)$ :696-706.

[9] Keramatikerman, M., Chegenizadeh, A., Nikraz, H., \& Sabbar, A. S. (2018). Effect of flyash on liquefaction behaviour of sand-bentonite mixture. Soils and foundations, 58(5), 1288-1296.

[10] Bain JA. A plasticity chart as an aid to the identification and assessment of industrial clays. Clay Minerals. 1971 Jul;9(1):1-7.

[11] Keramatikerman $M$, Chegenizadeh A, Nikraz $H$. (2017). Experimental study on effect of fly ash on liquefaction resistance of sand Soil Dynamics and Earthquake Engineering 93, 1-6

[12] Chegenizadeh, A., Nikraz, H. (2011). "Investigation on strength of fiber reinforced clay" Advanced Materials Research 261-263, pp. 957-963.

[13] Jan MA, Walker RD. Effect of lime, moisture and compaction on a clay soil. Highway Research Record. 1963(29).

[14] Chegenizadeh, A. and H. Nikraz, (2011). "Study on modulus of elasticity of reinforced clay" - Advanced Materials Research. 243-249: pp. 5885-5889, 2011.

[15] Chegenizadeh, A. and H. Nikraz, (2011). Composite Soil: Fiber Inclusion and Strength, Journal of Advanced Materials Research 1646

[16] Seed HB, Wookward RJ, Lundgren R. Clay mineralogical aspects of the Atterberg limits. Journal of Soil Mechanics \& Foundations Div. 1964 Jul;90(Proc. Paper 3983). 


\section{International Journal of Engineering Applied Sciences and Technology, 2020 \\ Vol. 4, Issue 11, ISSN No. 2455-2143, Pages 255-258 \\ Published Online March 2020 in IJEAST (http://www.ijeast.com)}

[17] Chegenizadeh, A. and H. Nikraz, (2012). Composite Clayey Sand and Short Fiber, Advanced Materials Research 383, 2764-2769

[18] Schmitz RM, Schroeder C, Charlier R. Chemomechanical interactions in clay: a correlation between clay mineralogy and Atterberg limits. Applied clay science. 2004 Aug 1;26(1-4):351-8.

[19] Chegenizadeh, A., Keramatikerman, M., \& Nikraz, H. (2018). Liquefaction resistance of fibre reinforced lowplasticity silt. Soil Dynamics and Earthquake Engineering, 104, 372-377.

[20] Jefferson I, Rogers CD. Liquid limit and the temperature sensitivity of clays. Engineering geology. 1998 Mar 6;49(2):95-109.

[21] Mikhail, M., Chegenizadeh, A., Keramatikerman, M., Burns, G., Terzaghi, S., Nikraz, H. (2020). Application of Cane Ash on Compressive Strength of Soil Uncovered to $\mathrm{MgSO}_{4}$. International Journal of Engineering and Advanced Technology (IJEAT) 9(4).

[22] Chegenizadeh A, Keramatikerman M, Panizza S, Nikraz H. (2017). Effect of powdered recycled tire on sulfate resistance of cemented clay. Journal of Materials in Civil Engineering. 2017 Oct 1;29(10):04017160.

[23] Muhunthan B. Liquid limit and surface area of clays. Geotechnique. 1991 Mar;41(1):135-8.

[24] Chegenizadeh, A., Keramatikerman, M., Dalla Santa, G., \& Nikraz, H. (2018a). Influence of recycled tyre amendment on the mechanical behaviour of soilbentonite cut-off walls. Journal of cleaner production, 177, 507-515

[25] Amiralian S, Chegenizadeh A, Nikraz H (2012) Laboratory investigation on the compaction properties of lime and fly ash composite, Proceedings of the International Conference on Civil and Architectural applications (ICCAA'2012) 79-83

[26] Chegenizadeh A, Aashish M, Nikraz H, Keramatikerman M. Sulphate Attack on Cemented-Bentonite-Coconut Coir. Results in Engineering. 2020 Mar 3:100111.

[27] Polidori E. Relationship between the Atterberg limits and clay content. Soils and foundations. 2007;47(5):887-96.

[28] Amiralian S, Chegenizadeh A, Nikraz H (2012) Laboratory investigation on the effect of lime on compressibility of soil, Proceedings of the International Conference on Civil and Architectural applications (ICCAA'2012) 89-93

[29] Keramatikerman, M., Chegenizadeh, A., Yilmaz, Y., \& Nikraz, H. (2018). Effect of Lime Treatment on Static Liquefaction Behavior of Sand-Bentonite Mixtures. Journal of Materials in Civil Engineering, 30(11), 06018017.

[30] Chegenizadeh, A., \& Keramatikerman, M. (2017). Mitigating sulphate attacks in geotechnical engineering Hauppauge, New York, USA Nova Science Publishers. (pp. 1-165).
[31] Keramatikerman M, Chegenizadeh A, Nikraz H. Effect of Slag on Restoration Mechanical Characteristics of Ethanol Gasoline-Contaminated Clay. Journal of Environmental Engineering. 2018 Jul 1;144(7):06018001.

[32] Chegenizadeh, A., Keramatikerman, M., Miceli, S., Nikraz, H., Salih Sabbar, A. (2020). Investigation on Recycled Sawdust in Controlling Sulphate Attack in Cemented Clay. Appl. Sci., 10, 1441.

[33] Keramatikerman, M., Chegenizadeh, A., \& Nikraz, H. (2017). An investigation into effect of sawdust treatment on permeability and compressibility of soil-bentonite slurry cut-off wall. Journal of Cleaner Production, 162, $1-6$.

[34] Chegenizadeh, A., Keramatikerman, M., \& Nikraz, H. (2016). Flexible pavement modelling using Kenlayer. EJGE, 21, 2467-2479.

[35] Keramatikerman, M., Chegenizadeh, A., \& Pu, H. (2017). Effect of atrazine contamination on compressibility and permeability characteristics of clay. Geotechnical Testing Journal, 40(6), 936-950.

[36] Chegenizadeh, A., Keramatikerman, M., Nikraz, H., Importance of Microstructural Analysis in Experimental Soil Stabilization. Global Journal of Engineering Science. 4(5): 2020.

[37] Al-Rkaby AHJ, Chegenizadeh A, Nikraz H. (2017). Anisotropic strength of large scale geogrid-reinforced sand:experimental study Soils and foundations 57 (4), $557-574$

[38] Srivastava A, Pandey S, Rana J. Use of shredded tyre waste in improving the geotechnical properties of expansive black cotton soil. Geomechanics and Geoengineering. 2014 Oct 2;9(4):303-11.

[39] Keramatikerman M, Chegenizadeh A, Nikraz H. Shear strength characteristics of over-consolidated clay treated with ggbfs. Australian Geomechanics Journal. 2018;53(2):141-9.

[40] Keramatikerman, M. (2018). Investigations into Effect of By-product Binders in Improvement of Cyclic Behaviour of Soil (Doctoral dissertation, Curtin University).

[41] Giasi CI, Cherubini C, Paccapelo F. Evaluation of compression index of remoulded clays by means of Atterberg limits. Bulletin of Engineering Geology and the Environment. 2003 Nov 1;62(4):333-40.

[42] Keramatikerman, M., Chegenizadeh, A., Nikraz, H. How Ground Improvement Addresses the United Nation Sustainable Development Goals: A Review. Current Trends in Civil \& Structural Engineering 5(3): 2020. CTCSE.MS.ID.000613.

DOI: 10.33552/CTCSE.2020.05.000613

[43] Esrig ML, Gemeinhardt JP. Electrokinetic stabilization of an illitic clay. Journal of Soil Mechanics \& Foundations Div. 1967;92(SM5, Proc Paper 490).

[44] Mikhail, M., Keramatikerman, M., Chegenizadeh, A., Terzaghi, S., Burns, G., Nikraz, H. (2020). Influence of 
Bagasse Ash on Compaction Behvaiour of Soil. International Journal of Innovative Technology and Exploring Engineering (IJITEE). 9(5).

[45] Das SK, Basudhar PK. Prediction of residual friction angle of clays using artificial neural network. Engineering Geology. 2008 Sep 1;100(3-4):142-5.

[46] Keramatikerman M, Chegenizadeh A. Effect of particle shape on monotonic liquefaction: Natural and crushed sand. Experimental Mechanics. 2017 Oct 1;57(8):1341-8. 